\title{
Methanol Oxidation in Alkaline Medium Using PtIn/C Electrocatalysts
}

\author{
M. C. L. Santos ${ }^{1}$ - C. A. Ottoni ${ }^{2}$ - R. F. B. de Souza ${ }^{3}$ - S. G. da Silva ${ }^{1}$ • \\ M. H. M. T. Assumpção ${ }^{4}$ E. V. Spinacé ${ }^{1} \cdot$ A. O. Neto $^{1}$
}

Published online: 17 August 2016

(C) Springer Science+Business Media New York 2016

\begin{abstract}
Pt} / \mathrm{C}$ and $\mathrm{PtIn} / \mathrm{C}$ with atomic ratios of 90:10, 70:30, and 50:50 were investigated for methanol electro-oxidation in alkaline media by using cyclic voltammetry (CV), chronoamperometry (CA), and direct methanol alkaline fuel cell (DMAFC). All electrocatalysts were synthesized using sodium borohydride method with $20 \mathrm{wt} \%$ of metals loading on carbon. X-ray diffraction (XRD) analysis revealed that bimetallic PtIn had faced centered cubic structure and, also, confirmed alloy formation for PtIn/C nanoparticles. Transmission electron micrographs showed metal nanoparticles with average particle size between 3.0 and $5.0 \mathrm{~nm}$; however, the particle size increases when the In content was increased in PtIn/C. In the CV experiments, the onset potential of methanol electro-oxidation shifted to lower values as the indium content increased. Chronoamperometry experiments and direct methanol alkaline fuel cell suggested PtIn/C (70:30) as the most promising material for methanol electrooxidation: this result could be explained by the presence of $\mathrm{Pt}$ and In in close contact (electronic effect) as the occurrence of oxy-hydroxy interactions.
\end{abstract}

A. O. Neto

aolivei@ipen.br

1 Instituto de Pesquisas Energéticas e Nucleares, IPEN/CNEN-SP, Av. Prof. Lineu Prestes, 2252 Cidade Universitária, CEP 05508-900 São Paulo, SP, Brazil

2 Bioscience Institute, Coastal Campus, São Paulo State University, 11380-972 São Vicente, SP, Brazil

3 Department of Chemistry, Federal University of Amazonas, 69077-000 Manaus, AM, Brazil

4 UFSCar-Campus Lagoa do Sino, Centro de Ciências da Natureza, Universidade Federal de São Carlos, Rodovia Lauri Simões de Barros, Km 12, CEP 18290-000, Buri, SP, Brazil
Keywords Methanol oxidation · PtIn electrocatalysts · Alkaline fuel cell

\section{Introduction}

Fuel cells are one of the most promising energy sources for application in portable devices, vehicles, and stationary devices [1]. In this context, polymer electrolyte membrane fuel cells (PEMFC) have attracted a great deal of attention due to a series of highly advantageous features, such as low operating temperature and sustained operation at high current density [2-4]. In the development of low temperature fuel cells, it is usually utilized organic molecules, such as methanol, ethanol, and formic acid, because they do not bring problems as to distribution and storage when compared to hydrogen gas [5]. Methanol is considered a promising system for energy conversion due to its high energy density $\left(702.32 \mathrm{~kJ} \mathrm{~mol}^{-1}\right)$ and it is really attractive because of its abundance, low cost, and convenience in production [6]. The development of an efficient catalyst for direct methanol fuel cell (DMFCs) is very important since the electrochemical study has shown that $\mathrm{CO}_{\mathrm{ads}}$, formic acid, and formaldehyde are the intermediary compounds in the oxidation of methanol in electrolyte acid on Pt electrodes. Methanol oxidation reaction in Pt involves the formation of several intermediates, such as dehydrogenation, $\mathrm{CO}$ chemisorption, adsorption of $\mathrm{OH}\left(\right.$ or $\left.\mathrm{H}_{2} \mathrm{O}\right)$, a chemical reaction between adsorbed $\mathrm{CO}$ and $\mathrm{OH}$ and evolution of $\mathrm{CO}_{2}[5,7]$.

Pt electrocatalyst has been considered the most promising electrode material for methanol oxidation; however, methanol oxidation produces the $\mathrm{CO}$ formation, which is strongly adsorbed on Pt active sites, and consequently, it is necessary to modify the vicinity of Pt atoms by adding other elements [8]. 
Pt-binary electrocatalysts have been reported as anodic electrocatalysts for DMFC, where different elements were combined with platinum, such as Ir [9], Pd [10], Rh [11], Ni [12], and $\mathrm{Ru}$ [13]. In these electrocatalysts, $\mathrm{Pt}$ is responsible for methanol activation to produce $\mathrm{CO}$, while the second metal ( $\mathrm{Ir}, \mathrm{Pd}, \mathrm{Rh}, \mathrm{Ni}$, or $\mathrm{Ru}$ ) is responsible for the $\mathrm{CO}$ conversion into $\mathrm{CO}_{2}$. Nevertheless, the development of more efficient electrocatalysts with lower affinity to $\mathrm{CO}$ is still a necessary point in order to achieve technological advances in DMFC [5].

Gonzalez [5] showed that the presence of In in the surroundings of small $\mathrm{Pt}$ particles favors easier $\mathrm{CO}$ oxidation to $\mathrm{CO}_{2}$ (observed in $\mathrm{CO}$ stripping measurements) and, also, a higher electrocatalytic activity (determined in DMFC experiments) was observed, in comparison with pure Pt.

Xin et al. [14] showed that PtSnIn catalyst had an enhanced activity for ethanol oxidation compared to both PtSn and PtIn catalysts, consistent with the results of a single-cell test. It was suggested that the enhanced ethanol oxidation activity of PtSnIn catalyst could be attributed to the electronic effect (formation of a ternary PtSnIn alloy).

Additionally, another way to improve the methanol oxidation is the use of alkaline media, where it is known that at high $\mathrm{pH}$ values, the kinetics of alcohol deprotonation is favored [15]. In alkaline media, the poisoning is considered smaller when compared to that in acid media [16]; furthermore, the oxygen reduction reaction has the kinetics favored [17].

In this context, the aim of this work was to prepare PtIn/C electrocatalysts by borohydride reduction process, in different $\mathrm{Pt} / \mathrm{In}$ atomic ratios, for methanol electro-oxidation in alkaline medium. This work includes both electrochemical (cyclic voltammetry and chronoamperometry) and single-cell experiments (real conditions of operation). The single cell experiments were carried out with $\mathrm{KOH}$-modified Nafion112 membrane, as already proposed by Sun et al. [18].

\section{Experimental}

The borohydride reduction method was used to prepare $\mathrm{Pt} / \mathrm{C}$, $\mathrm{In} / \mathrm{C}$ and PtIn/C electrocatalysts with $20 \mathrm{wt} \%$ of metal loading, where $\mathrm{PtIn} / \mathrm{C}$ eletrocatalysts were prepared with different atomic ratios of 90:10, 70:30 and 50:50. PtIn/C electrocatalyst was prepared using $\mathrm{H}_{2} \mathrm{PtCl}_{6} \cdot 6 \mathrm{H}_{2} \mathrm{O}$ (chloroplatinic acid, Aldrich), $\mathrm{InCl}_{3} . x \mathrm{H}_{2} \mathrm{O}$ (indium chloride hydrate- Aldrich) as metal sources, sodium borohydride (Aldrich) as reducing agent and Vulcan Carbon XC72 as support. In the borohydride reduction method, the Vulcan XC72 support and metal sources were dissolved in a mixture of water/2-propanol (50/ $50, v / v)$, then this mixture was submitted to an ultrasonic bath by $10 \mathrm{~min}$; afterwards, a solution of sodium borohydride was added in one portion, at room temperature; finally, the mixture was filtered and the solid was washed with water and dried at $70{ }^{\circ} \mathrm{C}$, for $2 \mathrm{~h}[19]$.
$\mathrm{X}$-ray diffraction patterns were recorded in the range of $2=20^{\circ}-90^{\circ}$, with a step size of $0.05^{\circ}$ and a scan time of $2 \mathrm{~s}$ per step. These studies were made in a Rigaku diffractometer model Miniflex II, with $\mathrm{Cu} \mathrm{K} \alpha$ radiation source of $-0.15406 \mathrm{~nm}$. The electrocatalysts prepared were also characterized by transmission electron microscopy using a JEOL JEM-2100 electron microscope, operated at $200 \mathrm{kV}$. In this work, it was determined the morphology, distribution, and size of the nanoparticles in the support, where the histogram was built by 120 particles measurements from a micrograph.

The electrochemical measurements (cyclic voltammetry and chronoamperometry) were carried out at room temperature, using an Autolab $302 \mathrm{~N}$ potenciostat. The experiments were performed in a three-electrode conventional cell, with the reference electrode of $\mathrm{Ag} / \mathrm{AgCl}\left(3 \mathrm{~mol} \mathrm{~L}^{-1} \mathrm{KCl}\right)$, a counter electrode of Pt wire and work electrode prepared in the form of thin porous coating technique [19]. The cyclic voltammetry experiments were done at a scan rate of $10 \mathrm{mVs}^{-1}$ in $1 \mathrm{~mol} \mathrm{~L}^{-1}$ $\mathrm{KOH}$ solution, with the presence or absence of $1.0 \mathrm{~mol} \mathrm{~L}^{-1}$ of methanol saturated with $\mathrm{N}_{2}$. Chronoamperometry (amperometric curves) was recorded in the same electrolyte containing methanol, at $-0.40 \mathrm{~V}$ for $1800 \mathrm{~s}$. All measurements were conducted at room temperature.

Direct alkaline methanol fuel cell tests were performed in a single cell with $5 \mathrm{~cm}^{2}$ of area, using $\mathrm{Pt} / \mathrm{C}$ and $\mathrm{PtIn} / \mathrm{C}$ as anode, with $1 \mathrm{mg}$ of $\mathrm{Pt}$ loading by $\mathrm{cm}^{2}$, while that a $\mathrm{In} / \mathrm{C}$ electrode was prepared with $1 \mathrm{mg}$ of In loading by $\mathrm{cm}^{2}$. As

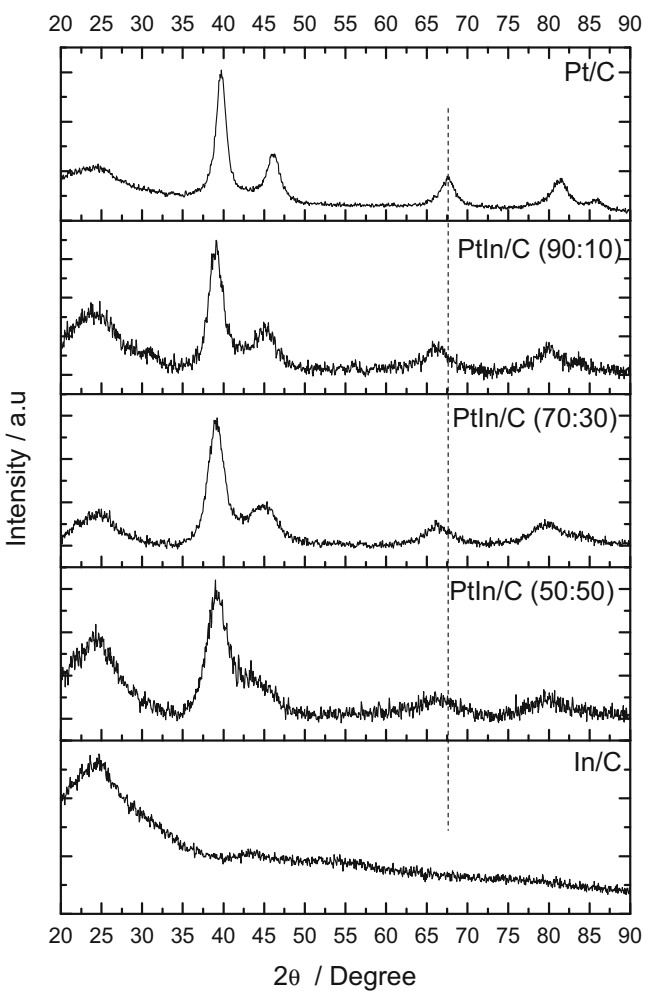

Fig. 1 X-ray diffractograms of the $\mathrm{Pt} / \mathrm{C}$, In/C, and PtIn/C electrocatalysts prepared by borohydride reduction process 
cathode, Pt/C BASF with $1 \mathrm{mg}$ of Pt loading by $\mathrm{cm}^{2}$ was used. The Nafion 117 membranes were exposed to $\mathrm{KOH}$ $6 \mathrm{~mol} \mathrm{~L}^{-1}$ for $24 \mathrm{~h}$, as it has already been proposed by Hou et al. [18]. The MEAS were prepared with hot pressure on both sides of a Nafion 117 membrane, at $125^{\circ} \mathrm{C}$ for $2 \mathrm{~min}$, under a pressure of $225 \mathrm{kgf} \mathrm{cm}{ }^{-2}$. The Polarization curves were obtained using a potentiostat/galvanostat, where methanol 1.0 and $2.0 \mathrm{~mol} \mathrm{~L}^{-1} \mathrm{KOH}$ were delivered at $1.0 \mathrm{~mL} \mathrm{~min}{ }^{-1}$ and the oxygen flow was regulated at $150 \mathrm{~mL} \mathrm{~min}^{-1}$.
Fig. 2 TEM images and histograms of the particle size distribution to $\mathrm{Pt} / \mathrm{C}$ and $\mathrm{PtIn} / \mathrm{C}$ electrocatalysts
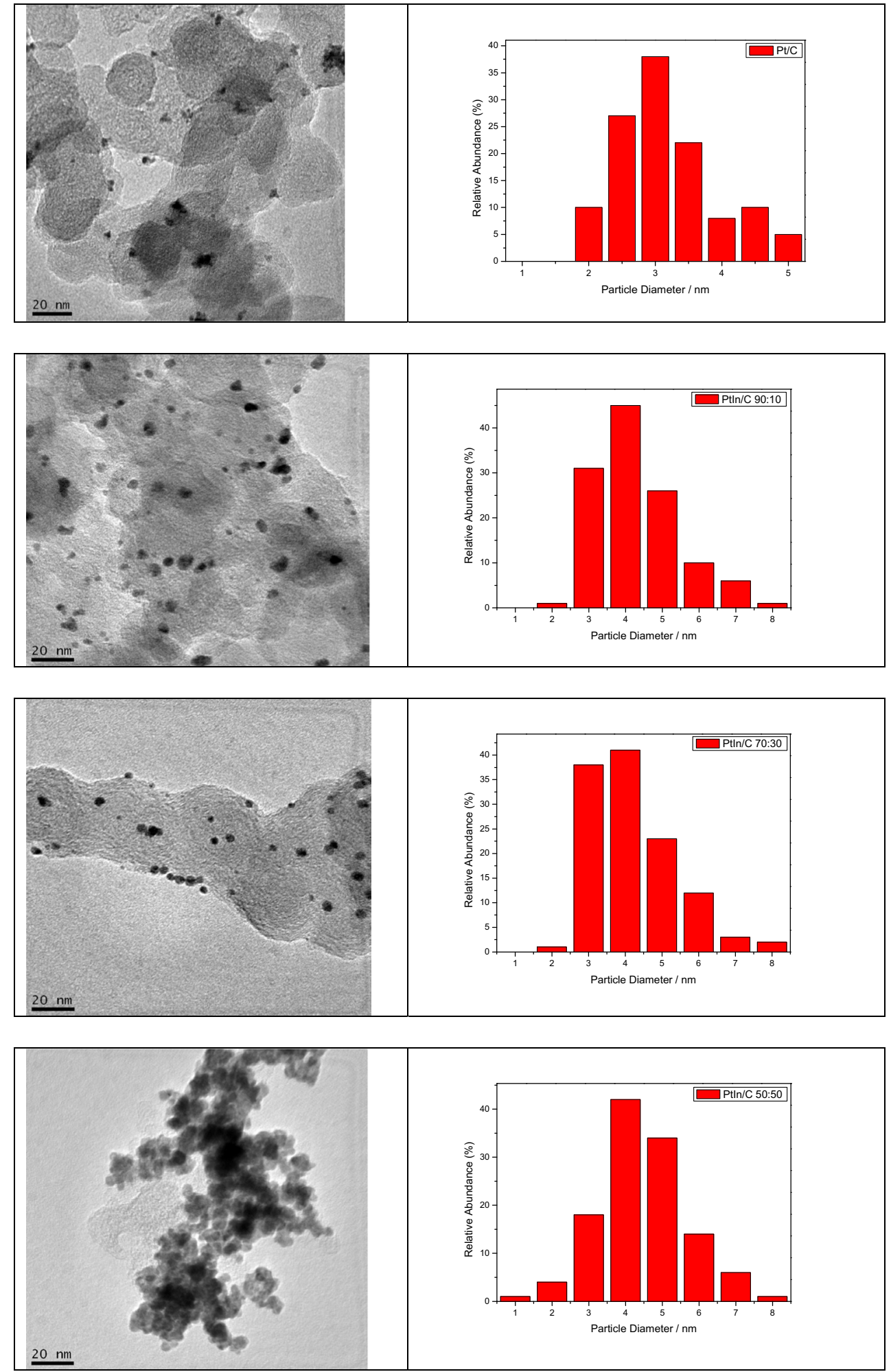


\section{Results and Discussion}

Figure 1 shows XRD patterns of $\mathrm{Pt} / \mathrm{C}$ and PtIn/C electrocatalysts prepared by borohydride reduction method. All diffractograms of $\mathrm{PtIn} / \mathrm{C}$ electrocatalysts indicated the presence of a face-centered cubic (fcc) structure. This structure is associated with the (111), (200), (220), and (311) planes, which appear at 2 values of $40^{\circ}, 46^{\circ}, 67^{\circ}$, and $80^{\circ}$, respectively. The diffraction peaks of PtIn/C electrocatalysts were shifted to lower 2 values in comparison with $\mathrm{Pt} / \mathrm{C}$ electrocatalysts; this effect is associated to the inclusion of In atoms to the fcc structure of Pt that is related to the formation of PtIn/C alloys. The formation of $\mathrm{PtIn} / \mathrm{C}$ alloy was also confirmed by crystal lattice parameter values, where $\mathrm{PtIn} / \mathrm{C}$ showed values of $0.399 \mathrm{~nm}$, while $\mathrm{Pt} / \mathrm{C}$ showed values of $0.392 \mathrm{~nm}$. The average crystallite size for $\mathrm{Pt} /$ $\mathrm{C}$ and $\mathrm{PtIn} / \mathrm{C}$ was obtained by using the Scherrer equation applied to the (220) plane and these values are in the range of $3.0-5.0 \mathrm{~nm}$.

In Fig. 2, the micrographs and histograms of the particle size distribution, obtained by transmission electronic microscopy for $\mathrm{Pt} / \mathrm{C}$ and $\mathrm{PtIn} / \mathrm{C}$ electrocatalysts, are illustrated. $\mathrm{Pt} / \mathrm{C}$, $\mathrm{PtIn} / \mathrm{C}$ (90:10), and PtIn/C (70:30) show a more homogeneous and narrower distribution of particle sizes than PtIn/C (50:50); however, the histograms with the mean diameter of nanoparticles for $\mathrm{Pt} / \mathrm{C}$ and $\mathrm{PtIn} / \mathrm{C}$ electrocatalysts are in the range of 3.0-5.0 $\mathrm{nm}$. In accordance with this work, Gonzalez [5] showed PtIn/C with particle sizes of $3.0 \mathrm{~nm}$.

Cyclic voltammograms of $\mathrm{Pt} / \mathrm{C}$ and $\mathrm{PtIn} / \mathrm{C}$ electrocatalysts prepared with different ratio in $1.0 \mathrm{~mol} \mathrm{~L}^{-1} \mathrm{KOH}$ are shown in Fig. 3, where the results were normalized by the amount of platinum in the electrocatalysts. All PtIn/C did not show a well-defined hydrogen oxidation region $(-0.85$ to $-0.60 \mathrm{~V}$ versus $\mathrm{Ag} / \mathrm{AgCl} 3.0 \mathrm{~mol} \mathrm{~L}^{-1} \mathrm{KCL}$ ) in comparison to pure platinum. This effect could indicate that there is coverage of platinum active sites by indium, as an occurrence with other

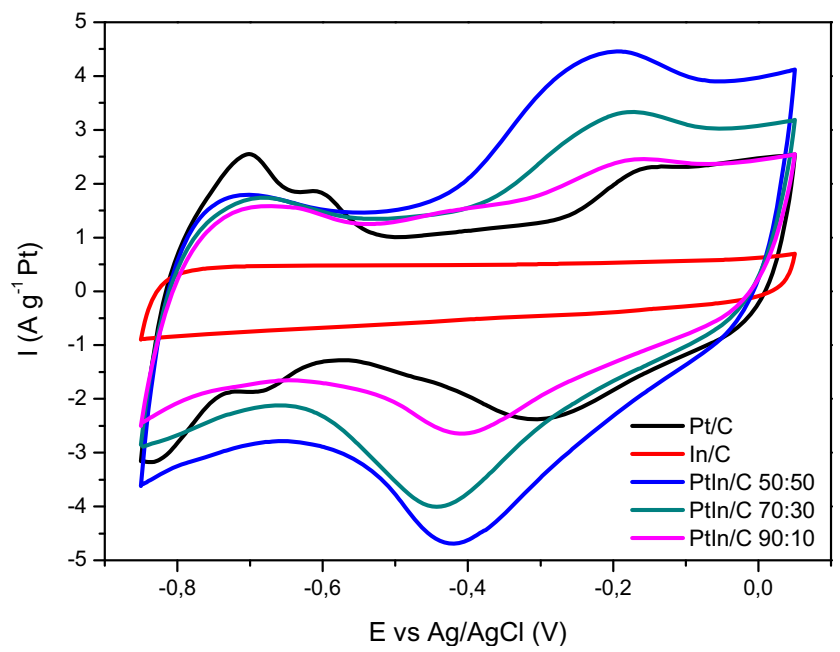

Fig. 3 Cyclic voltammograms of $\mathrm{Pt} / \mathrm{C}, \mathrm{In} / \mathrm{C}$ and $\mathrm{PtIn} / \mathrm{C}$ electrocatalysts in $1 \mathrm{~mol} \mathrm{~L}^{-1} \mathrm{KOH}$ solution with a scan rate of $10 \mathrm{mV} \mathrm{s}^{-1}$ at $25^{\circ} \mathrm{C}$ transition metals [21]. The cyclic voltammograms results also showed that indium is inactive for adsorption/desorption hydrogen. The current densities in the double layer region of $\mathrm{PtIn} / \mathrm{C}$ are larger than those in $\mathrm{Pt} / \mathrm{C}$, where the current values in the double layer region increased with the increase of In content; therefore, PtIn/C (50:50) presented the largest charge/ discharge current of the double layer in comparison with other electrocatalysts prepared. This effect has been observed for other binary electrocatalysts [21]. In anodic scan was observed a peak around $-0.25 \mathrm{~V}$ indicating the oxidation of In$\mathrm{O}$ species; the peak current increased with increasing Indium content. This behavior was also observed by Rambabu et. al. [22] for $\mathrm{In}_{2} \mathrm{O}_{3}$ supported $\mathrm{Pt} / \mathrm{C}\left(\mathrm{Pt} / \mathrm{C}-\mathrm{In}_{2} \mathrm{O}_{3}\right)$ electrocatalysts prepared by ethanol oxidation in acid medium.

Figure 4 shows the $\mathrm{CV}$ of $\mathrm{Pt} / \mathrm{C}, \mathrm{In} / \mathrm{C}$, and $\mathrm{PtIn} / \mathrm{C}$ with different atomic ratios 90:10, 70:30, and 50:50 in the presence of methanol $\left(1.0 \mathrm{~mol} \mathrm{~L}^{-1}\right)$ and $\mathrm{KOH}\left(1.0 \mathrm{~mol} \mathrm{~L}^{-1}\right)$ solutions, where the CVs were normalized by the amount of platinum in the electrocatalysts. Methanol oxidation starts at a potential of about $-0.60 \mathrm{~V}$ for PtIn/ $\mathrm{C}$ vs around $-0.55 \mathrm{~V}$ for the $\mathrm{Pt} / \mathrm{C}$. $\mathrm{PtIn} / \mathrm{C}$ (50:50) electrocatalysts showed the best electrocatalytic activity toward methanol electro-oxidation, when compared to PtIn/C (70:30), PtIn (90:10), Pt/C and In/C. PtIn/C (70:30) showed more activity that $\mathrm{Pt} / \mathrm{C}$, while that PtIn (90:10) showed similar performance in comparison with $\mathrm{Pt} / \mathrm{C}$ : finally, $\mathrm{In} / \mathrm{C}$ electrocatalyst was inactive toward methanol oxidation. This result showed bad activity of $\mathrm{In} / \mathrm{C}$ in alkaline media; however, the addition of In to Pt results in an increase in the activity in comparison with pure $\mathrm{Pt}$; this effect could be explained by the oxy-hydroxy interactions that occur in the catalytic layer, where the presence of oxygen species from indium oxides and $\mathrm{KOH}$ solutions favor the oxidation of poisoning intermediates, while the electronic effect is associated with the formation of PtIn alloys.

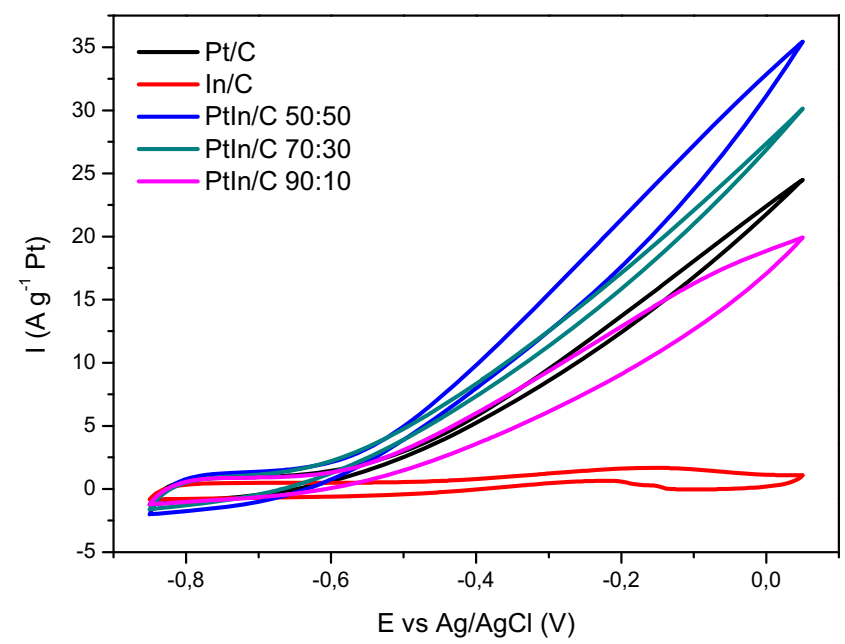

Fig. 4 Cyclic Voltammograms of $\mathrm{Pt} / \mathrm{C}, \mathrm{In} / \mathrm{C}$ and $\mathrm{PtIn} / \mathrm{C}$ electrocatalysts in $1 \mathrm{~mol} \mathrm{~L}^{-1}$ methanol solution in $1 \mathrm{~mol} \mathrm{~L}^{-1} \mathrm{KOH}$ with a scan rate of $10 \mathrm{mV} \mathrm{s}^{-1}$ at $25^{\circ} \mathrm{C}$ 
Figure 5 shows the chronoamperometry curves for $\mathrm{Pt} / \mathrm{C}, \mathrm{In} /$ $\mathrm{C}$ and PtIn/C electrocatalysts in the potential of $-0.4 \mathrm{~V}$, for $30 \mathrm{~min}$. The chronoamperommetry results showed, for all electrocatalysts prepared, a faster decay of current during the first minutes, followed by a slower decay. All PtIn/C electrocatalysts prepared were more active than $\mathrm{Pt} / \mathrm{C}$ and $\mathrm{In} /$ $\mathrm{C}$, for methanol oxidation. PtIn/C (70:30) showed higher current values after $1800 \mathrm{~s}$ at $-0.40 \mathrm{~V}$, followed by $\mathrm{PtIn} / \mathrm{C}$ (50:50), PtIn/C (90:10), Pt/C, and In/C. The current values obtained by chronoamperometry curves for PtIn/C (70:30) were about 3.5 times higher than those obtained with $\mathrm{Pt} / \mathrm{C}$, indicating that the introduction of In in Pt catalysts results in the improvement of methanol oxidation; this effect could also be explained by the oxy-hydroxy interactions that occur in the catalytic layer and the electronic effect. Xin et al. [14] showed that the activity of PtSnIn/C depends upon the In atomic content in the catalysts: these authors observed that when the atomic content of In increases from 0 to $20 \%$, the activity of the $\mathrm{PtSnIn} / \mathrm{C}$ catalyst is promoted; this effect was also related with the bifunctional mechanism and electronic effect. Neto et al. [23] showed that a Pt/C- $\mathrm{In}_{2} \mathrm{O}_{3} \cdot \mathrm{SnO}_{2}$ electrocatalyst had highest current values in all potential range $(0.05-0.8 \mathrm{~V})$ in comparison with $\mathrm{Pt} / \mathrm{C}$, for ethanol oxidation in acidic media. The better activity of Pt/C- $\mathrm{In}_{2} \mathrm{O}_{3} \cdot \mathrm{SnO}_{2}$ electrocatalyst was attributed to the bifunctional mechanism, where $\operatorname{In}_{2} \mathrm{O}_{3} \cdot \mathrm{SnO}_{2}$ (ITO) enhances the formation of chemisorbed oxygen species and promotes the oxidation of the intermediate adsorbed on the surface of platinum.

Figure 6 shows the performances of single alkaline methanol fuel cell with $\mathrm{Pt} / \mathrm{C}, \mathrm{In} / \mathrm{C}$, and $\mathrm{PtIn} / \mathrm{C}$, as anode electrocatalysts. The open circuit voltage for PtIn/C (50:50), PtIn/C (70:30), PtIn/C(90:10), and Pt/C were 0.91, 0.87, and $0.86 \mathrm{~V}, 0.83 \mathrm{~V}$, respectively. However, power density results indicated that PtIn/C (70:30) was more active than the other

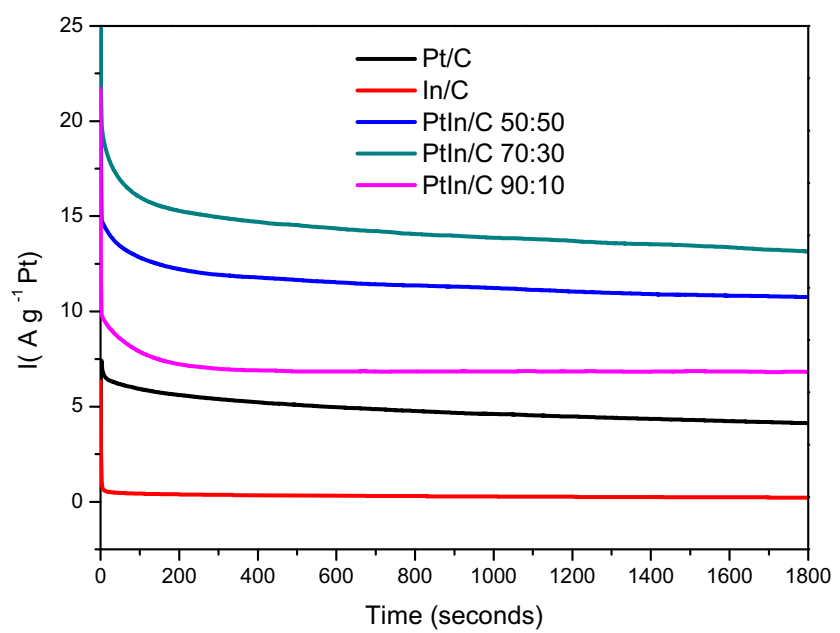

Fig. 5 Chronoamperometry curves at $-0.4 \mathrm{~V}$ in $1 \mathrm{~mol} \mathrm{~L}^{-1}$ methanol solution in $1 \mathrm{~mol} \mathrm{~L}^{-1} \mathrm{KOH}$ for $\mathrm{Pt} / \mathrm{C}, \mathrm{In} / \mathrm{C}$, and $\mathrm{PtIn} / \mathrm{C}$ electrocatalysts at $25{ }^{\circ} \mathrm{C}$
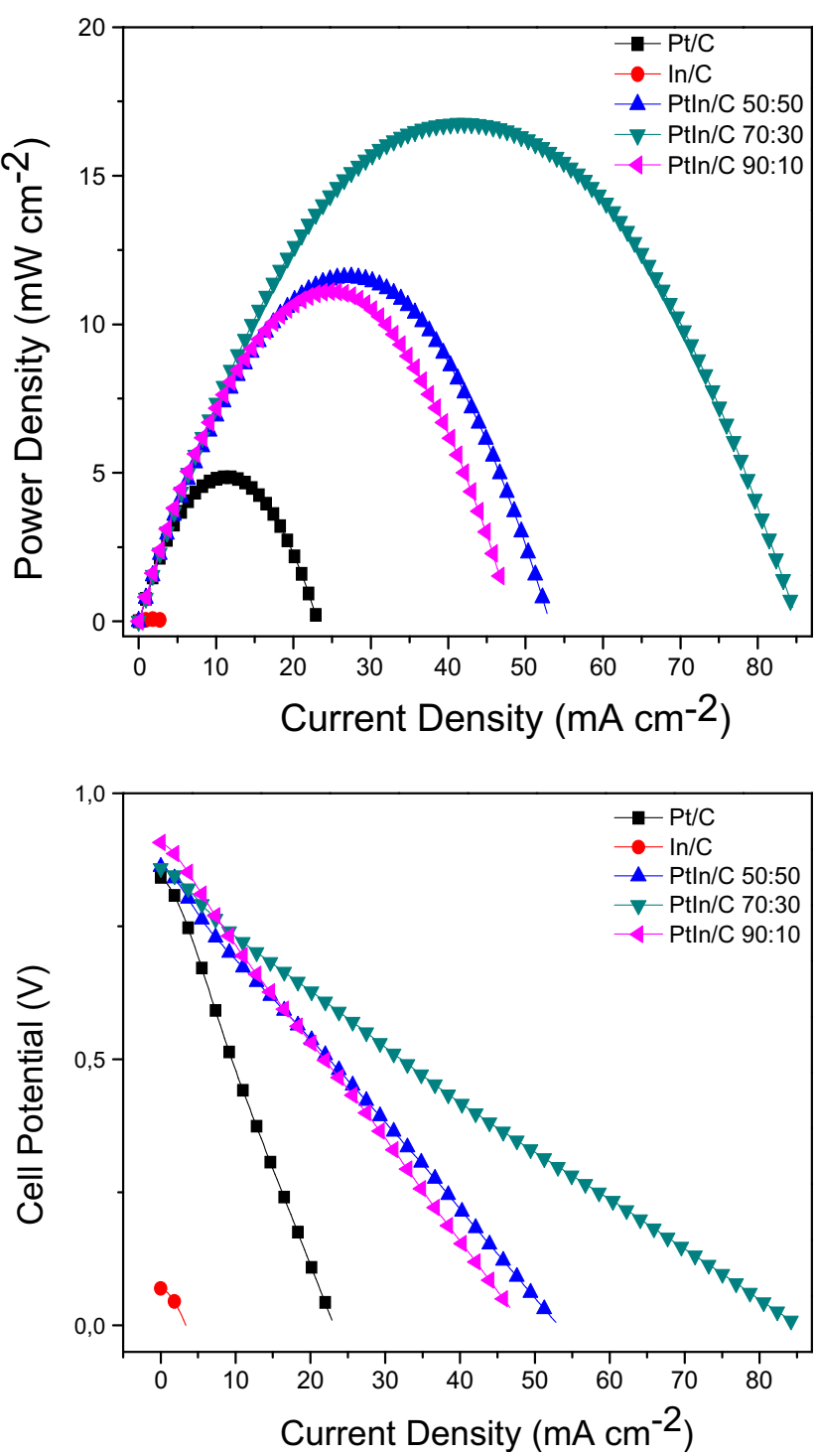

Fig. $6 \mathrm{I}-\mathrm{V}$ Curves and the power density at $80{ }^{\circ} \mathrm{C}$ of a $5 \mathrm{~cm}^{2}$ DAMFC using $\mathrm{Pt} / \mathrm{C}, \mathrm{In} / \mathrm{C}$, and PtIn/C electrocatalysts anodes $\left(1 \mathrm{mg}\right.$ metal $\mathrm{cm}^{-2}$ catalyst loading) and $\mathrm{Pt} / \mathrm{C}$ E-TEK electrocatalyst cathode $\left(1 \mathrm{mgPt} \mathrm{cm}{ }^{-2}\right.$ catalyst loading with $20 \mathrm{wt} \%$ Pt loading on carbon), Nafion $117 \mathrm{mem}-$ brane $\mathrm{KOH}$ treated, methanol $\left(1.0 \mathrm{~mol} \mathrm{~L}^{-1}\right)$ and oxygen pressure (2 bar)

materials prepared $\left(17 \mathrm{~mW} \mathrm{~cm}^{-2}\right)$, followed by PtIn/C (50:50) (12 $\left.\mathrm{mW} \mathrm{cm}^{-2}\right), \mathrm{PtIn} / \mathrm{C}(90: 10)\left(11 \mathrm{~mW} \mathrm{~cm}^{-2}\right)$, and $\mathrm{Pt} / \mathrm{C}$ $\left(5 \mathrm{~mW} \mathrm{~cm}^{-2}\right)$, while $\mathrm{In} / \mathrm{C}$ was inactive. The experiments on single DAMFC showed that the power density for PtIn/C (70:30) was almost 3.5 times higher than those obtained using $\mathrm{Pt} / \mathrm{C}$, confirming that the addition of In to Pt favors the methanol oxidation in alkaline media, which is in accordance with cyclic voltammetry and chronoamperommetry experiments. The improvement in methanol oxidation could be explained by the oxy-hydroxy interactions that occur in the catalytic layer and the electronic effect. Gonzalez et al. [5] showed that the presence of In in the surroundings of small Pt particles produces important promoter effects, both for an easier $\mathrm{CO}$ 
oxidation and for $\mathrm{CO}_{2}$, in acidic media. Xin et al. [14] showed that $\mathrm{PtSnIn} / \mathrm{C}$ has higher exporting voltage than $\mathrm{PtSn} / \mathrm{C}$ catalyst, in direct ethanol fuel cell. These authors concluded that the addition of In to PtSn catalyst promotes the ethanol oxidation activity, where the enhanced performance of PtSnIn/C catalyst is related to the excellent kinetic rate of EOR associated to bifunctional mechanism and electronic effect (ternary alloy phase of PtSnIn).

\section{Conclusion}

The borohydride reduction process produced effective PtIn/C electrocatalysts for methanol oxidation with mean particle size between 3.0 and $5.0 \mathrm{~nm}$. PtIn/C electrocatalysts showed the presence of a face-centered cubic (fcc) and the formation of a PtIn alloy. PtIn/C (70:30) exhibited higher performance for methanol oxidation in alkaline media, when compared to $\mathrm{Pt} /$ $\mathrm{C}$ and other PtIn/C electrocatalysts at room temperature and in direct alkaline methanol fuel cell. The best results obtained using PtIn/C (70:30) may be associated with the presence of oxy-hydroxy interactions that occur in catalytic layer, electronic effect and the presence of optimum atomic ratio for PtIn/C. Further research work is necessary to investigate the mechanisms of methanol oxidation using these electrocatalysts and to investigate the surface of these materials through XPS analysis.

Acknowledgments The authors thank the Laboratório de Microscopia do Centro de Ciências e Tecnologia de Materiais (CCTM) for TEM measurements and FAPESP (2014/09087-4), for the financial support.

\section{References}

1. J.C.M. Silva, R.F.B. De Souza, G.S. Buzzo, E.V. Spinacé, A.O. Neto, M.H.M.T. Assumpção, Ionics 20, 1137 (2014)
2. A. Esmaeilifar, M. Yazdanpour, S. Rowshanzamir, M.H. Eikani, Int J Hydrog Energy 36, 5500 (2011)

3. S. Thanasilp, M. Hunsom, Fuel 89, 3847 (2010)

4. T.S. Zhao, C. Xu, R. Chen, W.W. Yang, Prog Energy Combust Sci 35, 275 (2009)

5. N.S. Veizaga, V.A. Paganin, T.A. Rochab, O.A. Scelza, S.R. de Miguel, E.R. Gonzalez, Int J Hydrog Energy 39, 728 (2014)

6. K.S. Lee, I.S. Park, Y.H. Cho, D.S. Jung, N. Jung, H.Y. Park, Y.E. Sung, J Catal 258, 143 (2008)

7. S. Wen, Y. Fu, T. Wang, Y. Yu, J. Hu, RSC Adv 5, 79178 (2015)

8. A.S. Aricò, S. Srinivasan, V. Antonucci, Fuel Cells 1, 133 (2001)

9. L. Hong, Y. Hao, Y. Yang, J. Yuan, L. Niu, Nanotechnology 26, 045604 (2015)

10. W. Xie, F. Zhang, Z. Wang, M. Yang, J. Xia, R. Gui, Y. Xia, J Electroanal Chem 761, 55 (2016)

11. L. Li, C. Tian, J. Yang, X. Zhang, J. Chen, Int J Hydrogen Energy 40, 14866 (2015)

12. R. Xiu, F. Zhang, Z. Wang, M. Yang, J. Xia, R.G.Y. Xia, RSC Adv 5, 86578-86583 (2015)

13. Z. Yang, S. Xu, J. Xie, J. Liu, J. Tian, P. Wang, Z. Zou, J Appl Electrochem 25, 1-6 (2016)

14. M. Zhu, G. Sun, S. Yan, H. Li, Q. Xin, Energy Fuel 23, 403 (2009)

15. Y. Kwon, S.C.S. Lai, P. Rodriguez, M.T.M. Koper, J Am Chem Soc 133, 6914 (2011)

16. L. Colmenares, H. Wang, Z. Jusys, L. Jiang, S. Yan, G.Q. Sun, R.J. Behm, Electrochim Acta 52, 221 (2006)

17. A.D. Modestov, M.R. Tarasevich, A.Y. Leykin, V.Y. Filimonov, J Power Sources 188, 502 (2009)

18. H. Hou, S. Wang, W. Jin, Q. Jiang, L. Sun, L. Jiang, G. Sun, Int J Hydrog Energy 36, 5104 (2011)

19. C.A. Ottoni, S.G. da Silva, R.F.B. De Souza, A.O. Neto, Electrocatalysis 7, 22 (2016)

20. E.G. Franco, A.O. Neto, E.M. Arico, M. Linardi. J. Brazilian Chem. Soc. 4, 516 (2012)

21. S.G. da Silva, J.C.M. Silva, G.S. Buzzo, R.F.B. De Souza, E.V. Spinacé, A.O. Neto, M.H.M.T. Assumpção, Int J Hydrogen Energy 39, 10121 (2014)

22. J. Parrondo, R. Santhanam, F. Mijangos, B. Rambabu, Int J Electrochem Sci 5, 1342 (2010)

23. R.S. Henrique, R.F.B. De Souza, J.C.M. Silva, J.M.S. Ayoub, R.M. Piasentin, M. Linardi, E.V. Spinacé, M.C. Santos, A.O. Neto, Int J Electrochem Sci 7, 2036 (2012) 